\title{
Global Transformation of the Living Standards of Population in the Context of Spatial Transformations
}

\author{
Yulia Polozhentseva ${ }^{1 *}$ \\ ${ }^{1}$ South-West State University, Department of Regional Economics and Management, 305040, 94, 50 \\ let Oktyabrya str., Kursk, Russia
}

\begin{abstract}
.
Research background: The world is constantly changing, increasing the efficiency of economic processes and raising the standard of living of the population, but this development has an uneven tendency. The global transformation of socio-economic development provides an opportunity for the state to use all available potential in order to increase the level and quality of life of the population.

Purpose of the article: The main purpose of the publication is to study the dynamics of the development of the living standard of the population, to conduct a comparative analysis of the global indicators characterizing it.

Methods: The article provides a comparative analysis of countries, which makes it possible to structure the main components of the living standard of the population; the results of the rating assessment of world indices characterizing the standard of living of the population are systematized based on the methods of scientific knowledge, comparative and statistical analysis.

Findings \& Value added: The analysis of the dynamics of the main indicators of the standard of living of the population made it possible to identify the main trends in the influence of these indicators on the level of the country's development. Based on the comparison and analysis of world indicators, the place of Russia in the world economic space has been determined and an analysis of their dynamics has been carried out. Measures have been systematized to regulate the development of the standard of living of the population, aimed at eliminating crisis situations and imbalances in their development.
\end{abstract}

Keywords: living standard of the population; income level; spatial transformation; globalization, indicators

*Corresponding author polojenceva84@mail.ru 
JELClassification: $F 63 ; J 17 ; R 13$

\section{Introduction}

The modern world economy is in a state of constant movement, dynamism, modernization, and, in this regard, the uncertainty of the results of various changes has become its characteristic feature. Social stratification and differentiation of the population is an integral part of the life of society at any time, as well as the subject of study for economists around the world. At the present stage, negative changes in the standard of living (specifically, its decline) are becoming a factor, which determines the degree of satisfaction of the population with state policy.

Today a person, their rights and freedoms are the highest value, therefore, the question of the level of their well-being and general satisfaction with the quality of life arises. In general, the standard of living can be characterized as the degree of satisfaction of a person with their needs of a social and material nature [1,2]. The differentiation of the standard of living of the population is associated with a number of factors and reasons, among which one can identify the economic potential of the regions, the ability of the population to adapt to new economic activities, the structure and degree of employment of the population, social assistance and protection.

When addressing the standard of living, first of all, the material needs of people are considered, the satisfaction of which strongly depends on the level of human well-being and consumption. The activities of any country are primarily aimed at eliminating the problems arising among the population that prevent them from having a decent life.

Theoretical and practical aspects of research in the area of inequalities of the standard of living and the main indicators of their measuring are represented in the works of J. Poterba [3], D. Slesnick [4], D. Cutler and L. Katz [5], B. Mayer and J. Sullivan [6], G. Becker and N. Tomes [7], M. Klevtsova [8], Y.Vertakova [9],V. Plotnikov [10], D. Bilkov [11], E. Dalla Chiara, M. Menon F. and Perali [12], T. Gutfleisch and H.J. Andress [13], A. Kutter [14], N. D. Rao and J. Min [15], N. A. Samarskaya, N. V. Gorodnova and D. L. Skipin [16], N. U.Yarychiv, V. I. Kuznetsov and V. V. Rokotyanskaya [17], Yu. Zelenkov and E. Lashkevich [18], J. Zhu and W. Pulleyblank [19].

\section{Methodology}

The research is based on scientific methods, including generalization of domestic and foreign experience in assessing the standard of living of the population.Drawing on statistical methods, the authors have also considered and analyzed the dynamics of the main indicators of living standards of the population in the Russian Federation and abroad. The methodological base of research also includes scientific methods: the cause-and-effect approach; the structural and functional tools for pattern identification; methods of monographic analysis, as well as classical methods of analysis and synthesis, including private-scientific methods of economic phenomena research.

The basis of the research is a systematic approach, which allowed to systematize factors and measures to regulate the standard of living of the population in such countries as The United States of America, Canada, Great Britain, Sweden, Poland, Hungary, Malaysia, Russia, South Korea and others. Furthermore, on the basis of multivariate statistical analysis there has been considered the dynamics of the key indicators, which characterized the standard of living of the population, for the display of the results the methodology of graphic interpretation of information has been used. 


\section{Results and discussion}

At present, there is an acute social differentiation of the population's standard of living, which is influenced by various factors occurring in the world. Factors, as a category, are of two types: main and indirect. The main factors include specific events that have a direct impact on the standard of living and the situation in the world as a whole. Indirect factors only partially affect the population. It should be noted that the influence of any group of factors can have both positive and negative sides.

Countries with more efficient economies and significant societal wealth have the ability to provide their populations with high standards and to satisfy high demands. Countries with the highest percentage of the working population that is able to support the country's economy also have priority [20]. The next important factor in the differentiation of the standard of living is the state support of the population. This factor provides significant support to the population of any country, managing the standard of living. Social support can be provided in cash or in kind, in the form of services or benefits. There is a sufficient number of factors that influence the living standard. Every day world events become the levers that regulate the life and position of many people. The first priority of any government is to develop the necessary measures to manage the situation and maintain a high standard of living of the population.

One of the key indicators of the formation of the living standard is the Human Development Index (HDI) [21] - a complex indicator that characterizes the development of people in the countries worldwide (Table 1). Norway is the leader among countries with very high HDI in 2017-2019. The same group includes Australia, The Netherlands, Switzerland, Germany, Denmark, etc. The groups of countries with high and medium HDI were constantly changing over the period under review, which indicates the unevenness of the HDI. The ranking is closed by a group of countries with a low HDI, which, as noted above, occupy stable positions in 2017-2019: Mozambique, Sierra Leone, Burkina Faso, Eritrea, Mali and others. In general, progress is observed to a greater extent among countries with high and medium HDI, since it has the greatest turnover of positions.

Table 1. Dynamics of the human development index of the countries worldwide in 2017-2019

\begin{tabular}{|l|c|l|c|l|c|}
\hline \multicolumn{2}{|c|}{$\mathbf{2 0 1 7}$} & \multicolumn{2}{c|}{$\mathbf{2 0 1 8}$} & \multicolumn{2}{c|}{$\mathbf{2 0 1 9}$} \\
\hline \multicolumn{7}{|c|}{ Country } & HDI & \multicolumn{2}{c|}{ Country } & HDI & Country & HDI \\
\hline Norway & 0,949 & Norway & 0,954 & Norway & 0,954 \\
\hline Australia & 0,939 & Switzerland & 0,946 & Switzerland & 0,946 \\
\hline Switzerland & 0,939 & Ireland & 0,942 & Ireland & 0,942 \\
\hline Germany & 0,926 & Germany & 0,939 & Germany & 0,939 \\
\hline Denmark & 0,925 & Hong Kong & 0,939 & Hong Kong & 0,939 \\
\hline Singapore & 0,925 & Australia & 0,938 & Iceland & 0,938 \\
\hline The Netherlands & 0,924 & Iceland & 0,938 & Australia & 0,938 \\
\hline Ireland & 0,923 & Sweden & 0,937 & Sweden & 0,937 \\
\hline Iceland & 0,921 & Singapore & 0,935 & Singapore & 0,935 \\
\hline Canada & 0,92 & The Netherlands & 0,933 & The Netherlands & 0,933 \\
\hline \multicolumn{7}{|c|}{ Countries with high HDI } & \\
\hline Israel & 0,899 & Serbia & 0,799 & Spain & 0,893 \\
\hline Luxembourg & 0,898 & Trinidad & 0,799 & Czech Republic & 0,891 \\
\hline France & 0,897 & Iran & 0,797 & France & 0,891 \\
\hline
\end{tabular}




\begin{tabular}{|l|l|l|l|l|l|}
\hline Belgium & 0,896 & Mauritius & 0,796 & Malta & 0,885 \\
\hline Finland & 0,895 & Panama & 0,795 & Italy & 0,883 \\
\hline Austria & 0,893 & Costa Rica & 0,794 & Estonia & 0,882 \\
\hline Slovenia & 0,89 & Albania & 0,791 & Cyprus & 0,873 \\
\hline Italy & 0,887 & Georgia & 0,786 & Poland & 0,872 \\
\hline Spain & 0,884 & Sri Lanka & 0,780 & Greece & 0,872 \\
\hline Czech Republic & 0,878 & Cuba & 0,778 & Lithuania & 0,869 \\
\hline \multicolumn{7}{|c|}{ Countries with medium HDI } \\
\hline Seychelles & 0,782 & Marshall Islands & 0,698 & Iran & 0,797 \\
\hline Mauritius & 0,781 & Vietnam & 0,693 & Mauritius & 0,796 \\
\hline Trinidad & 0,78 & Palestine & 0,690 & Panama & 0,795 \\
\hline Costa Rica & 0,776 & Iraq & 0,689 & Costa Rica & 0,794 \\
\hline Serbia & 0,776 & Morocco & 0,676 & Albania & 0,791 \\
\hline Cuba & 0,775 & Kyrgyzstan & 0,674 & Georgia & 0,786 \\
\hline Iran & 0,774 & Guyana & 0,670 & Sri Lanka & 0,78 \\
\hline Georgia & 0,769 & El Salvador & 0,667 & Cuba & 0,788 \\
\hline Turkey & 0,767 & Tajikistan & 0,656 & St Kitts & 0,777 \\
\hline Sri Lanka & 0,767 & Cape Verde & 0,651 & Antigua & 0,776 \\
\hline \multicolumn{7}{|c|}{ Countries with low HDI } & & \\
\hline Eritrea & 0,42 & Mozambique & 0,446 & Mozambique & 0,446 \\
\hline Sierra Leone & 0,42 & Sierra Leone & 0,438 & Sierra Leone & 0,438 \\
\hline Mozambique & 0,418 & Burkina Faso & 0,434 & Burkina Faso & 0,434 \\
\hline South Sudan & 0,418 & Eritrea & 0,434 & Eritrea & 0,434 \\
\hline Guinea & 0,414 & Mali & 0,427 & Mali & 0,427 \\
\hline Burundi & 0,404 & Burundi & 0,423 & Burundi & 0,423 \\
\hline Burkina Faso & 0,402 & South Sudan & 0,413 & South Sudan & 0,413 \\
\hline Chad & 0,396 & Chad & 0,401 & Chad & 0,401 \\
\hline Niger & 0,353 & CAR & 0,381 & CAR & 0,381 \\
\hline CAR & 0,352 & Niger & 0,377 & Niger & 0,377 \\
\hline Compined by & & & & \\
\hline
\end{tabular}

Compiled by the author based on the book "Indices and Indicators of Human Development" http://hdr.undp.org/sites/default/files/2018_human_development_statistical_update_ru.pdf

An equally common index for studying the standard of living is the quality-of-life index, since these concepts are interrelated. The level of differentiation of the living standard depends on the quality-of-life index (Table 2). The ranking, which has been reviewed, includes the leading countries of 2017-2019 in terms of the quality-of-life index. Denmark, Switzerland, Finland and Australia retain their leading positions in 2018-2019. New Zealand drops below in the ranking positions every year.

Table 2. Ranking of countries by the quality-of-life index

\begin{tabular}{|l|c|l|c|l|c|}
\hline \multicolumn{2}{|c|}{$\mathbf{2 0 1 7}$} & \multicolumn{2}{c|}{$\mathbf{2 0 1 8}$} & \multicolumn{2}{c|}{ 2019 } \\
\hline \multicolumn{1}{|c|}{ Country } & QLI & \multicolumn{1}{c|}{ Country } & QLI & \multicolumn{1}{c|}{ Country } & QLI \\
\hline Norway & 190,22 & Denmark & 192,67 & Denmark & 196,47 \\
\hline Switzerland & 187,96 & Switzerland & 192,01 & Switzerland & 196,08 \\
\hline Canada & 183,22 & Finland & 190,22 & Finland & 195,06 \\
\hline Sweden & 180,57 & Australia & 186,21 & Australia & 189,73 \\
\hline New Zealand & 179,88 & The Netherlands & 183,67 & Iceland & 188,12 \\
\hline Denmark & 179,63 & Austria & 182,50 & Austria & 187,82 \\
\hline Australia & 177,81 & Iceland & 181,75 & $\begin{array}{l}\text { The } \\
\text { Netherlands }\end{array}$ & 186,41 \\
\hline
\end{tabular}




\begin{tabular}{|l|l|l|l|l|l|}
\hline Finland & 177,25 & New Zealand & 181,02 & Germany & 184,30 \\
\hline The Netherlands & 175,11 & Germany & 179,78 & New Zealand & 183,07 \\
\hline Luxembourg & 174,22 & Estonia & 177,82 & Sweden & 180,52 \\
\hline
\end{tabular}

Compiled by the author based on data from the statistical agency Numbeo

One of the determining factors of the living standard is the level of poverty of the population. Incomes of the population play a significant role in the formation of the living standard and allow maintaining its value. Countries with a high level of poverty naturally have a low standard of living, since the population is not able to meet many needs and acquire the necessary benefits [22]. The poverty level is formed by two main indicators - GDP and GDP per capita. The author suggests considering the dynamics of the poverty rate for 2017 2019 (Table 3).

Table 3.Ranking of countries by poverty level 2017-2019

\begin{tabular}{|l|l|c|l|c|l|l|}
\hline $\begin{array}{c}\text { Position } \\
\text { Year }\end{array}$ & Country & $\mathbf{2 0 1 7}$ & Country & $\mathbf{2 0 1 8}$ & Country & $\mathbf{2 0 1 9}$ \\
\hline \multicolumn{7}{|c|}{ GDP per capita (dollars per year) } \\
\hline 1 & $\begin{array}{l}\text { Central African } \\
\text { Republic }\end{array}$ & 656 & $\begin{array}{l}\text { Central African } \\
\text { Republic }\end{array}$ & 677 & $\begin{array}{l}\text { Central African } \\
\text { Republic }\end{array}$ & 600 \\
\hline 2 & Congo & 784 & Burundi & 735 & Burundi & 700 \\
\hline 3 & Burundi & 818 & Congo & 790 & Congo & 800 \\
\hline 4 & Liberia & 882 & Niger & 1164 & Niger & 1,1 \\
\hline 5 & Niger & 1100 & Malawi & 1167 & Malawi & 1,1 \\
\hline 6 & Malawi & 1140 & Mozambique & 1244 & Mozambique & 1,2 \\
\hline 7 & Mozambique & 1228 & Yemen & 1287 & Liberia & 1,3 \\
\hline 8 & Guinea & 1270 & Guinea & 1311 & Yemen & 1,5 \\
\hline 9 & Eritrea & 1320 & South Sudan & 1354 & Madagascar & 1,5 \\
\hline 10 & Madagascar & 1350 & Liberia & 1489 & South Sudan & 1,7 \\
\hline
\end{tabular}

Compiled by the author based on the source: "World Bank" [Electronic resource] Access mode: http://www.worldbank.org/

After analyzing the data in the table, it is possible to draw a conclusion about the rating, which includes the poorest countries with a backward economy and a low level of production development. There are many preconditions for this: from an ineffective model of the country's socio-economic development to armed conflicts taking place on the territory of the state. Basically, the ranking positions are occupied by African countries, where the standard of living is significantly lower than in developed countries. Having traced the dynamics, one can see that the positions of the countries have remained practically unchanged for 3 years, which indicates a weakened economy and a low standard of living of the population.

The author suggests considering further the ranking of the richest countries according to 2017-2019 data (Table 4). Having traced the dynamics of the indicators, it is worth noting that during the three years under review, the balance of the countries practically did not change. Most countries increase GDP per capita growth every year, remaining in the ranking of the 10 richest countries in the world. The rating is based on European countries with stable economies and high living standards.

Table 4. Ranking of the richest countries 2017-2019

\begin{tabular}{|l|c|c|c|}
\hline Country/ Year & $\mathbf{2 0 1 7}$ & $\mathbf{2 0 1 8}$ & $\mathbf{2 0 1 9}$ \\
\hline \multicolumn{4}{|c|}{ GDP per capita (dollars) } \\
\hline Quatar & 146000 & 129940 & 132900 \\
\hline Macao & 104500 & 110220 & 114360 \\
\hline Luxembourg & 94200 & 109200 & 108950 \\
\hline
\end{tabular}




\begin{tabular}{|l|c|c|c|}
\hline Singapore & 84800 & 90600 & 103108 \\
\hline Ireland & 70150 & 72700 & 83400 \\
\hline Brunei & 80300 & 76800 & 80380 \\
\hline Norway & 67600 & 70600 & 76680 \\
\hline UAE & 67200 & 68500 & 69430 \\
\hline Kuwait & 71000 & 70000 & 66390 \\
\hline Switzerland & 56800 & 61500 & 66200 \\
\hline
\end{tabular}

Compiled by the author based on the source: "World Bank" [Electronic resource] Access mode: http://www.worldbank.org/

Earlier it has been noted that the level of income has a significant impact on the differentiation of the population, since it regulates the material and social capabilities of a person. In this regard, it is necessary to consider the dynamics of income distribution between individual groups of the population (Fig. 1).

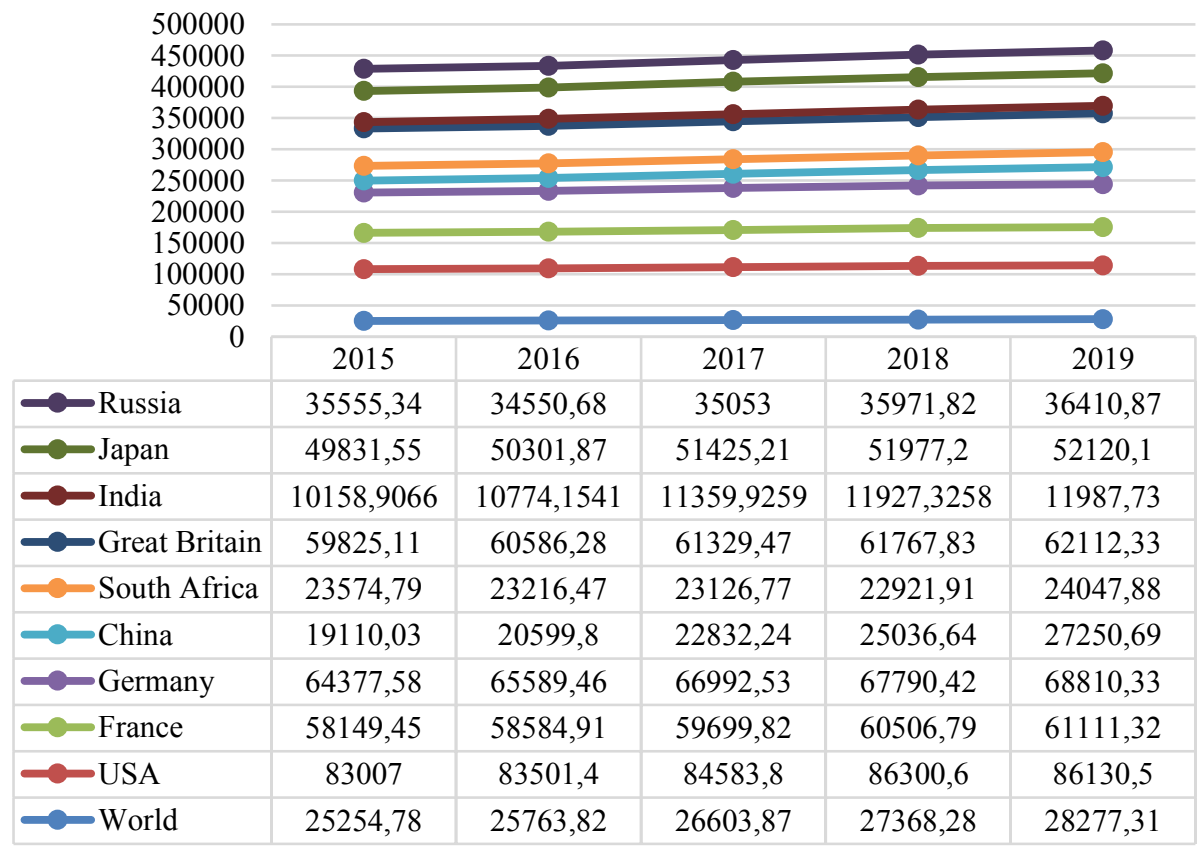

Fig. 1.Dynamics of average income per adult GDP, US dollars

Having considered the data in Figure 2, it should be concluded that positive dynamics of average income is observed in almost all countries under review: Russia, Japan, India, Great Britain, the United States and others. The highest growth rates are observed in the UK and Japan. In general, a significant lag can be observed in Russia, for 2019 the figure was \$ 36401.87 , which is $\$ 49719.63$ less than that of the United States, the world leader.

The main income of any person is mostly wages. The author suggests considering the indicators of the average salary level in different countries (Table 5).

Table 5. Average salary level in different countries

\begin{tabular}{|c|c|c|}
\hline \multicolumn{3}{|c|}{ Year } \\
\hline 2017 & 2018 & 2019 \\
\hline \multicolumn{3}{|c|}{ Russia } \\
\hline $37899 \mathrm{rub}$ & $42364 \mathrm{rub}$ & $46324 \mathrm{rub}$ \\
\hline
\end{tabular}




\begin{tabular}{|c|c|c|}
\hline Growth rate & 48,1 & 44 \\
\hline \multicolumn{3}{|c|}{ The USA } \\
\hline $294813 \mathrm{rub}$ & $350000 \mathrm{rub}$ & $329280 \mathrm{rub}$ \\
\hline Growth rate & 29,2 & 21 \\
\hline \multicolumn{3}{|c|}{ China } \\
\hline 98158 rub & $102913 \mathrm{rub}$ & $109585 \mathrm{rub}$ \\
\hline Growth rate & 10,4 & 10,6 \\
\hline
\end{tabular}

There is a significant difference in the level of wages among the countries under consideration, for example, the country with the largest indicator for the entire period under review (2017-2019) is the United States. In China, there is a constant increase in salary in relation to the previous year (4755 rubles by 2018, and 6671 rubles by 2019). In Russia, over three years, there has also been an annual increase in wages (4465 rubles by 2018 and 3960 rubles by 2019), while in the United States there is an increase of 55187 rubles by 2018 and a decrease in 2019 in relation to 2018 by 20720 rubles. In general, the average level of wages in the considered countries shows that salary is growing and it simulates an increase in the standard of living.

One of the key factors in the analysis of the standard of living is the indicator of the number of labor force. Two parts can be distinguished in the structure of labor resources from the perspective of their participation in social production: active (functioning) and passive (potential). Age limits are established in each country by existing legislation. The author suggests considering the ranking of the countries with the largest number of labor resources in 2017-2019 (Table 6).

Table 6. Ranking of countries with the largest labor force in 2017-2019

\begin{tabular}{|c|c|c|c|}
\hline Country/ Year & 2017 & 2018 & 2019 \\
\hline \multicolumn{4}{|c|}{ The number of labor resources, million people } \\
\hline China & 801,3 & 805,6 & 807,3 \\
\hline India & 511,2 & 519,1 & 523,5 \\
\hline The USA & 110,3 & 123,3 & 154,3 \\
\hline Indonesia & 98,2 & 104,0 & 112,0 \\
\hline Brazil & 87,1 & 89,9 & 93,7 \\
\hline Russia & 64,1 & 68,9 & 75,7 \\
\hline Bangladesh & 54,9 & 62,7 & 70,9 \\
\hline Japan & 52,3 & 59,7 & 66,5 \\
\hline Niger & 50,2 & 50,5 & 51,0 \\
\hline Pakistan & 50,1 & 50,4 & 50,6 \\
\hline
\end{tabular}

Compiled by the author based on the source: Eurostat [Electronic resource] Access mode:

https://ec.europa.eu/eurostat/portal/page/portal/statistics/search_database

The dynamics of growth in the number of labor resources is constantly increasing, which indicates the renewal of the countries' labor potential. In general, the high rates of labor force indicate a successful economy and an ever-increasing number of jobs necessary for the labor force. Labor employment determines not only the well-being of the country, but also maintains the standard of living of citizens, because a steady job means getting salary that forms the income of the population and stimulates people to successfully meet their needs. However, there are also countries with a low labor force indicator (Table 7).

Table 7. Ranking of countries with the lowest labor force in 2017-2019

\begin{tabular}{|c|c|c|c|}
\hline Country/Year & $\mathbf{2 0 1 7}$ & $\mathbf{2 0 1 8}$ & $\mathbf{2 0 1 9}$ \\
\hline \multicolumn{4}{|c|}{ The number of labor resources, million people } \\
\hline
\end{tabular}




\begin{tabular}{|l|l|l|l|}
\hline Liechtenstein & 32,1 & 32,2 & 32,4 \\
\hline Antigua & 28,1 & 28,7 & 30,0 \\
\hline Dominica & 24,3 & 24,7 & 25,0 \\
\hline San Marino & 22,1 & 22,5 & 22,7 \\
\hline St Kitts & 17,7 & 18,0 & 18,2 \\
\hline FSM & 15,7 & 15,9 & 16,4 \\
\hline Marshall Islands & 13,9 & 14,2 & 14,7 \\
\hline Palau & 9,1 & 9,4 & 9,8 \\
\hline Kiribati & 6,9 & 7,1 & 7,9 \\
\hline Tuvalu & 2,5 & 3,4 & 3,6 \\
\hline
\end{tabular}

Compiled by the author based on the source: Eurostat [Electronic resource] Access mode:

https://ec.europa.eu/eurostat/portal/page/portal/statistics/search_database

Shattered economy, low life expectancy, health problems are the main reasons for the low labor force. First of all, in order to improve the quality and stimulate the growth of labor, it is necessary to create stable jobs, establish a fixed amount of wages, and create favorable conditions for working.

In conclusion it should be noted that the results of the analysis of the standard of living by various indicators indicate that in recent years the standard of living in most countries of the world has been at an acceptable level. An effective mechanism for reducing differentiation and raising the standard of living is state policy aimed at solving many issues of the population, in particular, of an economic nature. The reduction in global inequality occurs to the greatest extent through the reduction of inequality among countries, ensuring economic security and reducing social tensions. Raising and maintaining a decent standard of living is a statewide problem that can be solved by joint efforts of all levels of government. The priority basis for management is a consistent increase in the standard of living of the population, reduction of poverty, the creation and implementation of decent living conditions for people.

When developing and making decisions aimed at improving living standards, it is necessary to rely on the following guidelines (Table 8).

Table 8. The main guidelines required for the development of state policy to improve the standard of living of the population

\begin{tabular}{|l|l|}
\hline \multicolumn{1}{|c|}{ Guideline } & \multicolumn{1}{c|}{ Characteristics } \\
\hline $\begin{array}{l}\text { Improving the } \\
\text { quality of life }\end{array}$ & $\begin{array}{l}\text { Positive dynamics in improving conditions that form the quality of } \\
\text { life: income, socio-cultural sphere, a decrease in the unemployment } \\
\text { rate and an increase in the share of the population with incomes } \\
\text { above the subsistence level and minimum wages }\end{array}$ \\
\hline $\begin{array}{l}\text { Providing } \\
\text { employment for } \\
\text { the population }\end{array}$ & $\begin{array}{l}\text { Increasing qualified personnel, increasing the level of labor force } \\
\text { mobility, supporting the labor and entrepreneurial initiative of } \\
\text { citizens }\end{array}$ \\
\hline $\begin{array}{l}\text { Increasing the } \\
\text { availability and } \\
\text { quality of social } \\
\text { services }\end{array}$ & $\begin{array}{l}\text { Development and implementation of programs for social support of } \\
\text { the population, development of the healthcare system, improvement } \\
\text { of the demographic situation, development of the education and } \\
\text { culture system }\end{array}$ \\
\hline $\begin{array}{l}\text { Provision of } \\
\text { affordable } \\
\text { housing }\end{array}$ & $\begin{array}{l}\text { Creation of infrastructure for comfortable living of the population, } \\
\text { support of some segments of the population in need of housing, } \\
\text { improvement of mortgage conditions and improvement of the } \\
\text { housing and communal services sector }\end{array}$ \\
\hline
\end{tabular}




\begin{tabular}{|l|l|}
\hline $\begin{array}{l}\text { Ensuring and } \\
\text { organizing safety } \\
\text { for the } \\
\text { population }\end{array}$ & $\begin{array}{l}\text { Equipping public spaces with security systems, carrying out } \\
\text { measures to prevent crimes of various kinds, creating conditions } \\
\text { against terrorist threats to the population }\end{array}$ \\
\hline
\end{tabular}

Source: compiled by the author

The standard of living is an indicator of the effectiveness of the entire public administration, since the destermination to improve public administration is one of the priority tasks of the strategic development of society, associated with the recent government reforms to improve the living standards of the population.

\section{Conclusion}

It is possible to conclude that the differentiation of living standards is a complex economic process that depends on many factors of varying degrees of significance. The existing imbalances in the socio-economic development of countries and regions in particular reflect the degree of influence of reforms on the standard of living of the population.The most important role in the formation of differentiation of the standard of living is played by the level of income and the level of well-being of the population, since they are the economic component of the standard of living. The countries with the highest percentage of the wealthy are mainly Asian and European. A high indicator reflects a successful economy and a high standard of living.

One of the key factors in the analysis of the standard of living is the indicator of the number of labor resources, since it forms a part of the able-bodied society capable of independently increasing the level of its income. High indicators of labor incomes reflects a successful economy and an ever-increasing number of jobs required by the labor force. Labor employment determines not only the well-being of the country, but also maintains the standard of living of citizens, because a steady job means getting salary that forms the income of the population and stimulates people to successfully meet their needs. This requires reforms in the field of public management of living standards based on the development of an optimal model of interaction between regions and the federal center. This should result in the formation of a stable tendency in the socio-economic development.

Acknowledgments: The study was carried out as part of the state task of South-West State University, the project code is 0851-2020-0034.

\section{References}

1. Pigou, A. C. (1932). The Economics of Welfare (4th ed.) London: Macmillan and Co.

2. Bell, D. (1973). The coming of post-industrial society: A venture of social forecasting. N.Y.: Basic Books

3. Poterba, J. (1989). Lifetime Incidence and the distributional burden of excise taxes. American Economic Review, 79(2), 325-30.

4. Slesnick, D. (1993). Gaining ground: poverty in the postwar United States. Journal of Political Economy, 101(1), 1-38.

5. Cutler, D., \& Katz, L. (1992). Rising Inequality? Changes in the distribution of income and consumption in the 1980's. American Economic Review, 82(2), 546-551.

6. Meyer, B., \&Sullivan, J. (2003). Measuring the Well-Being of the Poor Using Income and Consumption. Journal of Human Resources, 38, 1180-1220. 
7. Becker, G. S., \& Tomes, N. (1986). Human capital and the rise and fall of families. Journal of labor economics, 4(3, Part 2), S1-S39.

8. Vertakova, Y., Polozhentseva, Y., Klevtsova, M. (2019) Rating of the Global Differentiation Level of Socio-Economic Development of Countries. Proceedings of the 34th International Business Information Management Association Conference - Vision 2020: Innovation Management, Development Sustainability, and Competitive Economic Growth, 4421-4430.

9. Vertakova, Yu., Polozhentseva, Yu., Plotnikov, V., \& Isaev, M. (2015) Directions of Human Potential Development in Russia. Procedia Economics and Finance. 23, 495500.

10. Plotnikov, V., Vertakova, Y., \& Polozhentseva, Y. (2015). Methods of detecting imbalances in the structure and dynamics of socio-economic system. Political sciences, law, finance, economics and tourism: finance, economics and tourism, 2, 821-828.

11. Bilkov, D. (2020). Wage Level as One of the Most Important Indicators of the Quantitative Aspect of the Standard of Living of the Population and Selected Indicators of Economic Maturity in OECD Member Countries. Inzinerine EkonomikaEngineering Economics, 31(3), 334-344.

12. Dalla Chiara, E.; Menon, M.; Perali, F. (2019). An Integrated Database to Measure Living Standards. Journal of Official Statisctics, 35(3), 531-576.

13. Gutfleisch, T.; Andress, H.J.(2020). Perceptions of Society's Necessary Standard of Living: Are Perceptions Determined by What People Have, or Do They Reflect a Social Consensus?. Social Indicators Research, 149(2), 467-502.

14. Kutter, A. (2020) . Construction of the Eurozone crisis: re- and depoliticising European economic integration. Journal of European Integration, 42(5), 659-676.

15. Rao, N. D.; Min, J. (2018). Decent Living Standards: Material Prerequisites for Human Wellbeing. Social Indicators Research, 138 (1), 225-244.

16. Samarskaya, N. A., Gorodnova, N. V., Skipin, D. L., \& Peshkova, A. A. (2019). Improving the Standard of Living of the Population under the Modern Economic Conditions. In 34th International-Business-Information-Management-Association (IBIMA) Conference (pp. 881-897). International Business Information Management Association, IBIMA.

17. Yarychiv, N. U.; Kuznetsov, V. I.; Rokotyanskaya, V. V. (2019). Monitoring Living Standards of the Population of the Region. Revista Inclusiones, 6(SI), 306-317.

18. Zelenkov,Yu., Lashkevich, E. (2020). Fuzzy Regression Model of the Impact of Technology on Living Standards. Biznes Informatika-Business Informatics, 14(3), 6781.

19. Zhu, J., Pulleyblank, W. (2020). Determining a Positive Casual Relationship of Immigration on Living Standards. Journal of International Migration and Integration, 21(4), 1043-1056.

20. Polozhentseva, Y. (2016). Inequality in social standard of living in the international context. Економічний часопис-XXI, 157(3-4 (1)), 15-18.

21. Lind, N. (2019). A Development of the Human Development Index. Social Indicators Research, 146(3), 409-423.

22. Korikov, A.M. (2018). System theory and system analysis: a tutorial - M.: INFRA-M, Economics, organization and management in industries and spheres of activity, 2(12), 288. 